\title{
ITGA4 wt Allele
}

National Cancer Institute

\section{Source}

National Cancer Institute. IT GA4 wt Allele. NCI Thesaurus. Code C97748.

Human IT GA4 wild-type allele is located in the vicinity of 2 q31.3 and is approximately 81

$\mathrm{kb}$ in length. This allele, which encodes integ rin alpha-4 protein, plays a role in the modulation of both leukocyte adhesion and migration. 